\title{
The Epigenetics of Aging in Invertebrates
}

\author{
Guixiang Yu ${ }^{1, \dagger}$, Qi Wu ${ }^{1, \dagger}$, Yue Gao ${ }^{1}$, Meiling Chen ${ }^{1}$ and Mingyao Yang $1,2, * \mathbb{C}$ \\ 1 Institute of Animal Genetics and Breeding, Sichuan Agricultural University, Chengdu 611130, China; \\ yugx1102@163.com (G.Y.); 18728153863@163.com (Q.W.); 18227553815@163.com (Y.G.); \\ erinchenmeiling@163.com (M.C.) \\ 2 Farm Animal Genetic Resources Exploration and Innovation Key Laboratory of Sichuan Province, Sichuan \\ Agricultural University, Chengdu 611130, China \\ * Correspondence: yangmingyao@sicau.edu.cn; Tel.: +86-28-028-86290991 \\ + These authors contributed equally to this work.
}

Received: 2 August 2019; Accepted: 12 September 2019; Published: 13 September 2019

\begin{abstract}
Aging is an unstoppable process coupled to the loss of physiological function and increased susceptibility to diseases. Epigenetic alteration is one of the hallmarks of aging, which involves changes in DNA methylation patterns, post-translational modification of histones, chromatin remodeling and non-coding RNA interference. Invertebrate model organisms, such as Drosophila melanogaster and Caenorhabditis elegans, have been used to investigate the biological mechanisms of aging because they show, evolutionarily, the conservation of many aspects of aging. In this review, we focus on recent advances in the epigenetic changes of aging with invertebrate models, providing insight into the relationship between epigenetic dynamics and aging.
\end{abstract}

Keywords: aging; crosstalk; DNA methylation; histone modification; ncRNA

\section{Introduction}

Aging is an inevitable, time-dependent process in most living organisms, which involves functional decline, a steady increase in a plethora of chronic diseases, and ultimately death [1]. According to different biological scales, aging can be divided into "four layers": (I) the organism's decline in physical function and increased susceptibility to diseases; (II) systemic immune, metabolic and endocrine dysfunction; (III) cellular malfunction; and (IV) failure of biomolecular maintenance [2]. Epigenetics mainly acts in layers three and four, but also impacts other levels. Much research on aging has focused on genetic manipulation, and changing the activity of numerous genetic pathways can lead to lifespan extension in model organisms, for example, the insulin/Insulin-like growth factor-1) pathway (IIS), Target of rapamycin (TOR) signaling, Adenosine $5^{\prime}$-monophosphate (AMP)-activated protein kinase (AMPK) and sirtuins [3]. However, recently more attention has focused on epigenetic changes, which have come to be considered one of the hallmarks of aging [4]. Chromatin structure is altered because of the loss of histone protein during aging [5]. There is global DNA hypomethylation during ontogenesis [6]. Most brain functions, including synaptic plasticity, learning and memory, decline with age when epigenetic changes occur, including changes in microRNA (miRNA) levels [7,8]. Studies have showed that aging in humans is also associated with epigenetic drift [9]. Model animals, such as Caenorhabditis elegans and Drosophila melanogaster, have been long used for the study of aging. Worms and fruit flies have natural advantages because of their short life cycles, being easy to house and feed, the power of available genetic manipulations, and the conservation of many mammalian aging signaling pathways. The average lifespan is 2 to 3 weeks for $C$. elegans at $20^{\circ} \mathrm{C}$, and 70 days for Drosophila at $25^{\circ} \mathrm{C}$ [10]. Simple models have provided valuable insights into the aging process; for example, the IIS signaling pathway was first discovered in C. elegans and was later found to be 
conserved in both insects and mammals, where it regulates the rate of aging [11]. Therefore, this review will summarize recent advances in the roles of epigenetic changes in aging in these two invertebrates.

\section{DNA Methylation in Invertebrate Aging}

DNA methylation is a covalent chemical modification, which usually occurs at 5-methyl cytosine $(5 \mathrm{mC})$ and which is enriched in cytosine phosphate guanine (CpG) dinucleotides [12]. CpG methylation within promoters leads to transcriptional repression through the formation of compact chromatin structures such as heterochromatin. Conversely, promoters of genes that are highly expressed are devoid of DNA methylation, hence their name- $\mathrm{CpG}$ islands [13]. The dynamic changes in DNA methylation can impact aging and health. The local methylation level increases while the global methylation level decreases with aging [14]. Age-related DNA methylation changes are also correlated with human age-related diseases, such as cancer and sarcopenia $[15,16]$. Cytosine methylation is catalyzed by three DNA methyltransferases (DNMTs): DNMT1, DNMT3a, and DNMT3b. Three ten-eleven translocation (TET) proteins initiate the specific demethylation of $5 \mathrm{mC}$ residues in DNA: TET1, TET2, and TET3 [17]. The schematic diagram of DNA methylation and demethylation is shown in Figure 1. Worms do not encode a conventional DNA methyltransferase to silence DNA repeats, which led to the prevailing view that DNA methylation does not occur in C. elegans [18]. Similarly, in adult D. melanogaster, only a low level of DNA methylation was confirmed $[19,20]$. In Drosophila, overexpression of the DNA methyltransferase gene, dDnmt2, extends lifespan in a small heat shock protein-dependent way [21]. However, although $5 \mathrm{mC}$ methylation is rare, methylation on N6 adenine (6mA) is prevalent in C. elegans and D. melanogaster [22,23]. Recent studies have confirmed that NMAD-1 (MT-A70 family) and DMAD (DNA 6mA demethylase, TET ortholog) are 6mA demethylases in C. elegans and D. melanogaster, respectively. DAMT-1 (AlKB family) is likely a $6 \mathrm{~mA}$ methyltransferase in C. elegans [24]. NMAD-1 and DAMT-1 can regulate 6mA levels and control the epigenetic inheritance of phenotypes associated with the loss of the H3K4me2 demethylase spr-5 [22]. The worm mutant of spr-5 displayed a transgenerational increase in H3K4me2 and $6 \mathrm{~mA}$ levels coupled with a transgenerational fertility defect [22,25]. The double mutant of spr-5 and nmad-1 accelerates the progressive fertility defect, while the double mutant suppressed the transgenerational fertility defect in the spr-5 single mutant [22]. Furthermore, spr-5, nmad-1 and admt-1 can regulate $6 \mathrm{~mA}$; therefore, it is supposed that an appropriate level of $6 \mathrm{~mA}$ may be necessary to maintain normal fertility. DMAD was required for Drosophila development because transheterozygous mutants were either embryonically lethal or died within 3 days post-eclosion. In the ovary, DMAD-mediated $6 \mathrm{~mA}$ demethylation is correlated with transposon expression [23]. DMAD depletion in the Drosophila brain results in brain developmental defects by $6 \mathrm{~mA}$ accumulation. It was found that $6 \mathrm{~mA}$ dynamic regulation by DMAD coordinates with trithorax and polycomb-mediated epigenetic mechanisms [26]. However, there is no direct convincing evidence of a link between $6 \mathrm{~mA}$ and aging so far, to which more attention should be paid. 


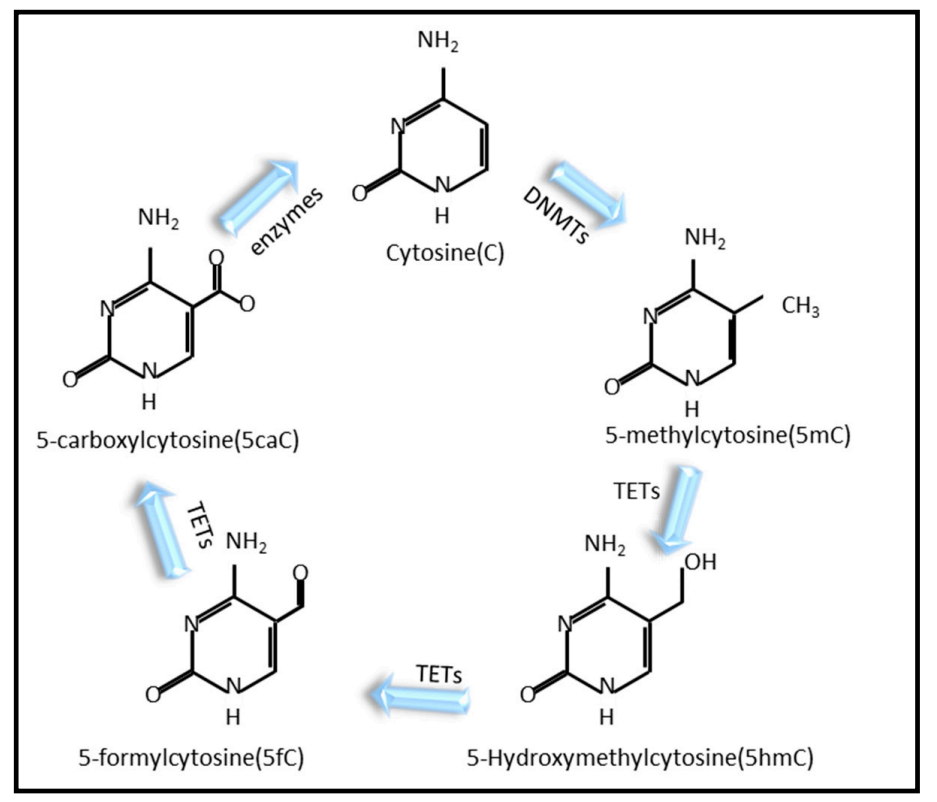

Figure 1. DNA methylation and demethylation. DNA cytosine methylation is catalyzed by DNA methyltransferases (DNMTs) to form 5-methylcytosine $(5 \mathrm{mC})$. Then, it can be oxidized iteratively by ten-eleven translocation (TET) protein to develop to 5-hydromethylcytosine (5hmC), 5 -formylcytosine (5fC), and 5-carboxylcytosine (5caC), respectively. Finally, 5-carboxylcytosine (5caC) can be demethylated into the cytosine through the catalysis of a series of enzymes. Figure modified from Kohli and Zhang (2013) [17].

\section{Histone Modifications in Invertebrate Aging}

Nucleosomes, the basic structures of eukaryotic chromatin, are made up of dimers of each core histone ( $\mathrm{H} 2 \mathrm{~A}, \mathrm{H} 2 \mathrm{~B}, \mathrm{H} 3$ and $\mathrm{H} 4)$. Histone modifications provide another layer of regulation beyond the DNA sequence itself. During the aging of organisms, the level of histone gradually decreases $[5,13,27]$ but histone modifications show different changes. Histone modifications comprise several types, such as methylation, acetylation, phosphorylation and ubiquitylation [28]. Methylation and acetylation are thought to be most well-characterized modifying methods associated with aging [29]. Here, we will discuss those two types of modifications (Figure 2).

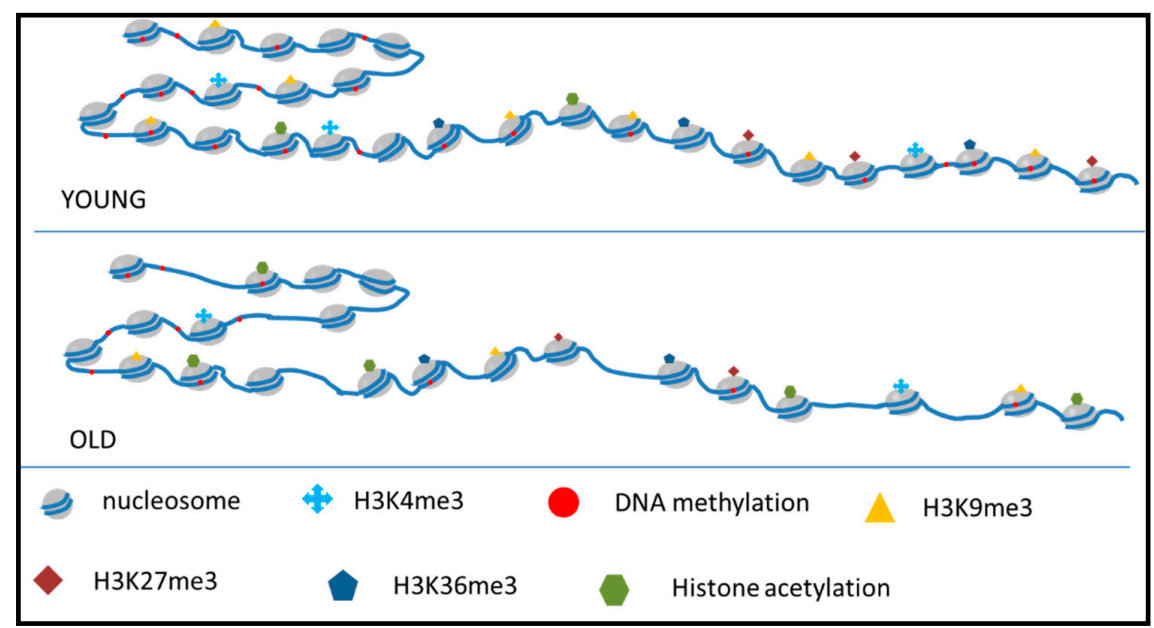

Figure 2. Histone modification changes during aging. During aging, DNA shows hypomethylation. A global loss of histone protein makes the chromatin structure looser. Histone methylation and acetylation show dynamic changes with age. These changes work together to contribute to the aging process. 


\subsection{Histone Methylation in Invertebrate Aging}

Histone methylation often takes place on lysine residues and is associated with aging in C. elegans and D. melanogaster. Like DNA methylation, histone methylation also requires methyltransferases and demethylases. Histone methyltransferases and demethylases are called KMTs/HMTs and KDMs/HDMs, correspondingly. We will review the roles of H3K4me3, H3K9me3, H3K27me3 and H3K36me3 associated with aging, respectively.

\subsubsection{H3K4me3}

H3K4me3 is an epigenetic chemical modification involved in the regulation of gene expression. H3K4me3 showed diverse changes with age in worms. The canonical pattern surrounding the transcriptional start sites, which marks the $5^{\prime}$ end of genes [30], is established at an early stage during development and then remains stable with age. Non-conventional H3K4me3 regions preferentially mark gene bodies and are acquired during adulthood, and they further show age-dependent changes, which increase with age [31]. There are three major complexes responsible for generating H3K4me3 in mammals: the COMPASS complex, the Trithorax complex and the Trithorax-related complex [32]. Deficiencies of ASH-2, WDR-5, and SET-2 (H3K4 methyltransferases in the COMPASS complex) reduce global H3K4me3 levels at the larval L3 stage and extend worm lifespan [33]. Knockdown or mutation of RBR-2 from H3K4me3 demethylase was able to increase the level of $\mathrm{H} 3 \mathrm{~K} 4 \mathrm{me} 3$ and then decrease lifespan. This affects the lifespan of animals in a germline-dependent manner [33]. Histone methylation has been implicated in transgenerational epigenetic regulation in C. elegans [34]. The loss of WDR-5.1 or SET-2 in worms impairs the transmission of stress adaptation in the progeny [35].

It was reported that there are still links between chromatin modifiers and fat metabolism. In C. elegans, the COMPASS H3K4me3 methyltransferase deficiency extends lifespan and promotes fat accumulation with a specific enrichment of mono-unsaturated fatty acids (MUFAs) in the intestine, by upregulating delta-9 fatty acid desaturase. This process acts mostly in the germline to regulate intestinal fat accumulation and lifespan, implying a germline-to-intestinal communication [36]. Importantly, these complexes can target RSKS-1/S6K in the germline, which is a key conserved substrate of mTOR complex 1 [37]. This suggests that the histone modification can act on mTOR signaling pathways to extend lifespan (Figure 3).

A connection between metabolism and epigenetics also exists in Drosophila. Reduced levels of some enzymes involved in methionine metabolism disrupt its metabolism, which directly affects histone methylation levels. For example, the reduction of little imaginal discs (LID), the H3K4me3 demethylase, can counter the effects on histone methylation due to reduction of SAM-S (S-adenosylmethionine synthetase) [38]. However, the effect of LID in Drosophila lifespan is sex-specific, as the male Drosophila is more sensitive to the loss of LID-dependent H3K4me3 demethylation than the female [39]; however, the molecular mechanism for this remains unclear. Hcf (the Drosophila homolog of Hos cell factor 1) associates with the histone H3K4 methyltransferase Trithorax-related (Trr) to maintain H3K4 monoand tri-methylation, regulating the Hippo pathway, which controls tissue and organ size through the regulation of cell proliferation and apoptosis [40].

Mutations in KDM5, another H3K4me3 demethylase, contribute to cognitive defects in flies and humans [41,42]. KDM5 can also regulate component genes of the immune deficiency (IMD) signaling pathway and maintain the host-commensal bacteria homeostasis in a demethylase-dependent manner. It was recently shown that a Drosophila mutant deficient in $k d m 5$ displayed gut dysbiosis, abnormal social behavior, and aberrant immune activation, and these phenotypes can be improved by Lactobacillus plantarum administration. This suggested a link between the gut microbiome and intellectual disability patients [43]. From all these results, H3K4me3 might act as a pro-aging factor to regulate lifespan. 


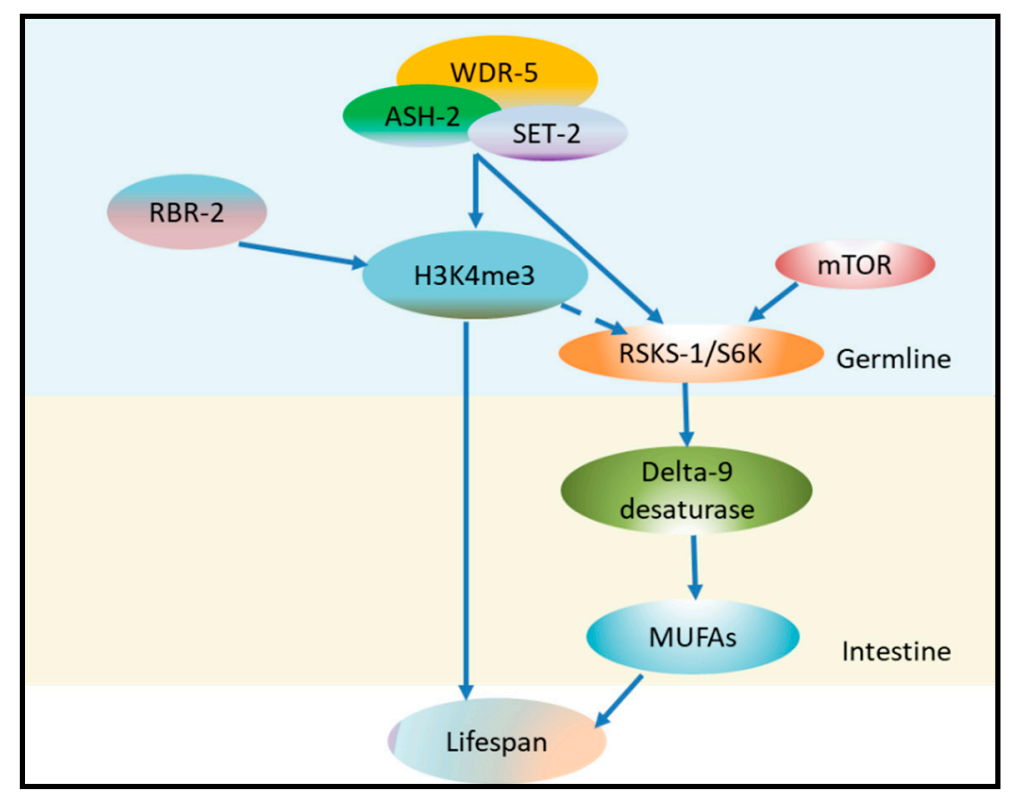

Figure 3. H3K4me3 regulates worm lifespan in a germline-dependent manner. RBR-2 demethylates H3K4me3, and the mutant of RBR-2 promotes the level of H3K4me3 and decreases lifespan. WDR-5, ASH-2 and SET-2 are the H3K4 methyltransferase complex, and the mutant in each one of them can diminish H3K4me3 level and prolong lifespan. The complex also directly or indirectly (dotted line) targets RSKS-1/S6K (a key conserved substrate of mTOR complex 1), which upregulates the delta-9 desaturase in the intestine, leading to mono-unsaturated fatty acid (MUFA) accumulation and extension of lifespan.

\subsubsection{H3K9me3}

H3K9me3 is a further covalent methylation of histone protein. One of the HMTs that has been identified in C. elegans is histone-modifying enzyme MET-2, which targets H3K9. It was reported that MET-2 associates with a conversed DNA repair protein SMRC-1, which limits DNA damage and promotes DNA replication and repair and genome stability in the germline in worms [44]. Recently, JMJD-1.2 was found to have a demethylase activity towards several lysine residues on Histone 3 (H3) in C. elegans. Jmjd-1.2 is expressed abundantly in the germline, where it controls the level of H3K9/K23/K27me2 both in mitotic and meiotic cells. However, jmjd-1.2 mutants are more sensitive to replication stress, and the progeny of mutant animals exposed to hydroxyurea show increased embryonic lethality and mutational rate, which suggests a role for jmjd-1.2 in the maintenance of genome integrity after replication stress [45]. Since genomic instability is one of the hallmarks of aging and is influenced by histone modification, we hypothesize that these hallmarks interact with each other during aging, making the mechanisms of aging more complicated. Associated with silenced heterochromatin regions, H3K9me3 serves as the binding site for heterochromatin protein 1 (HP1), which plays roles in heterochromatin formation, stabilization, and propagation [46]. In aged flies, the enrichment of $\mathrm{H} 3 \mathrm{~K} 9 \mathrm{me} 3$ and HP1 was strikingly reduced. There is also an age-related change in the nuclear organization of H3K9me3 and HP1. Nuclei of fat body cells from young animals show a characteristic intensely concentrated staining for $\mathrm{H} 3 \mathrm{~K} 9 \mathrm{me}$, while older animals show a more diffuse staining pattern [47]. Meanwhile, in the adult Drosophila mid-gut, the loss and dispersion of H3K9me3 and HP1 leads to the loss of chromatin stability in intestinal cells with age. Knockdown of su(var)3-9, methyltransferase for $\mathrm{H} 3 \mathrm{~K} 9 \mathrm{me} 3$ or $\mathrm{HP} 1 \alpha$ leads to intestinal stem cell (ISC) aging through genomic stress, JNK signaling, and apoptotic death in ECs [48]. The KDM4 family is highly conserved across species and reverses di- and tri-methylation of histone H3 lysine 9 (H3K9) and lysine 36 (H3K36). In Drosophila, $\mathrm{Kdm} 4$ is necessary for development because loss-of-function mutants do not survive past the early second instar larvae stage [49]. Apoptosis and DNA damage were involved in lethality [49]. 
Shown by the above evidence, H3K9me3 may contribute to DNA damage and genomic instability to promote the aging process.

\subsubsection{H3K27me3}

Like H3K9me3, H3K27me3 is another typical epigenetic mark, which usually denotes transcriptional silencing. H3K27me3 levels increased in aged flies [50]. Polycomb repressive complex 2 (PRC2) is a multiprotein complex that catalyzes the methylation of H3K27. In Drosophila, heterozygous mutations in $E(z)$ and $E S C$, both being core subunits of PRC2, increase longevity and reduce adult levels of H3K27me3 [51]. Mutations in trithorax (trx), which is an antagonist of polycomb silencing and a methyltransferase for H3K4me3, elevate the H3K27me3 level of $E(z)$ mutants and suppress their increased longevity. The mutants in $E(z)$ and esc exhibit increased resistance to oxidative stress and starvation, and these phenotypes are suppressed by trx mutations too [51]. These results suggest that the H3K4me3 Trx complex and the H3K27me3 PRC2 complex may work together to regulate animal lifespan. Metabolic homeostasis is intimately connected with aging and lifespan regulation [52]. A reduction of H3K27me3 by PRC-deficiency promotes healthy lifespan in a glycolysis-dependent manner, as perturbing glycolysis diminishes the pro-lifespan benefits mediated by PRC-deficiency [50]. The C. elegans SET domain protein MES-2, an ortholog of E(z) (a subunit of PRC2), provides H3K27 methylation activity [53]. RNAi against mes-2 extends lifespan significantly in wild type C. elegans. This also shows that the mechanism of life extension is independent of the germline [54].

The protein complex UTX-1 is a type of histone demethylase specific for H3K27me3, and it is a marker linked to chromatin repression. Recent work has shown that KDM6A/UTX is the target of metformin in prolonging lifespan through altering global H3K27me3 levels in mice [55]. The mutant of $u t x-1$ in flies raises the H3K27me3 level, limiting lifespan by downregulating glycolytic genes [50]. However, global somatic H3K27me3 levels decrease with age in germline-deficient worms [56]. RNAi of the $u t x-1$ gene extends the mean lifespan of $C$. elegans by $30 \%$ [57]. Meanwhile, both knockdown and heterozygous mutations of $u t x-1$ extend lifespan and increase the global levels of the H3K27me3 mark in worms [56]. Unlike H3K4me3, which extends lifespan mostly in a germline-dependent manner, H3K27me3 demethylase UTX-1 regulates lifespan independently of the presence of the germline, but in a manner that depends on the insulin-FOXO signaling pathway [56]. The catalytic enzyme utx-1 has an opposite effect on lifespan in flies and worms because it targets different genes in regulating lifespans. Most importantly, this phenomenon is mainly accomplished by different change patterns of H3K27me3 in aged flies and worms, increasing in aged flies but decreasing in aged worms. This suggests that only the optimal levels of H3K27me3 can maintain a healthy lifespan.

\subsubsection{H3K36me3}

H3K36me3 is a histone modification associated with active transcription, which plays crucial roles in a wide range of biological processes. A number of enzymes catalyze H3K36me. Loss of Rph1, a K36me2/3 demethylase, increases H3K36me3 level and extends lifespan in yeast [58]. Deficiency in the methyltransferase met-1 results in globally decreased H3K36me3, an increase in global mRNA expression change with age, and a shortened lifespan in C. elegans [59]. This indicates that global mRNA change level is negatively correlated with H3K36me3. H3K36me3 facilitates genomic stability via the promotion of DNA damage repair, both in DNA mismatch repair and double strand break pathways [60]. The suppression of spurious transcriptional initiation within the gene bodies involving a Set2/SETD2 (methyltransferase of H3K36) mechanism can ensure the fidelity of gene transcription [61]. While SET-18 is the H3K36 dimethyltransferase, a set-18 worm mutant extends lifespan and increases oxidative stress resistance in a daf-16-dependent manner. The level of muscle-specific set-18 is activated in aged worms (day 7 and day 11), attributable to the promotion of H3K36me2 and the inhibition of daf-16a expression; subsequently, longevity is shortened [62]. These results indicate that H3K36me3 and H3K36me2 have different roles in aging. H3K4me3 extends lifespan via maintaining transcription fidelity and genomic stability, while H3K36me2 causes limited lifespan through the IIS pathway. 


\subsection{Histone Acetylation in Invertebrate Aging}

Histone acetylation on lysine residues is another common histone modification, which plays a very important role in longevity regulation due to the direct connection with transcription promotion. Similar to methylation, it also requires the involvement of many enzymes, such as histone acetyltransferases (HATs) and histone deacetylases (HDACs). It was found that levels of H4K12ac, H3K9ac and H3K23ac increased in the midlife of Drosophila, compared with younger animals [63]. Early exposure to some mild stresses can slow down the aging process and extend lifespan through epigenetic changes. Histone acetylation levels of worms are increased under mild heat stress and are maintained into old age [64]. The expression of immune and detoxification genes also increased after such heat stress [64]. Histone acetyltransferase CBP-1 and the chromatin remodeling SWI/SNF complex (switch/sucrose non-fermenting, also known as the BAF complex) act as epigenetic modulators of the long-lasting defense responses [64]. When there is a decrease in the histone H4K12-specific acetyltransferase chameau, aging-associated phenotypes (such as raised oxygen consumption and acetyl-CoA levels as well as associated transcriptome changes) are alleviated, and longevity is prolonged [63]. In the meantime, Acetyl-CoA is a key metabolite in the TCA cycle and a cofactor for the acetylation of lysine residues, lowering the activity of the acetyl-CoA-synthesizing enzyme ATP citrate lyase (ATPCL), and also promoting longevity and retarding aging-associated changes [63]. Indeed, histone acetylation patterns are susceptible to alterations in key metabolites such as acetyl-CoA and $\mathrm{NAD}^{+}$, allowing chromatin to function as a sensor of cellular metabolism [65]. This implies that basical metabolism could be coupled with the aging process via lysine acetylation. Recent evidence indicates that histone lysine acetylation is tightly involved in the control of learning and memory [66]. Loss of $d C B P$, an acetyltransferase catalyze H3K23 in Drosophila, can decrease H3K23ac levels and impair neuronal gene activation, resulting in defective courtship learning [67]. These results imply that acetylation at different lysine residues may have opposite effects on aging.

Members of the sirtuin family of NAD-dependent protein deacetylases and ADP ribosyltransferases have been studied extensively as potential anti-aging factors. Overexpression of SIR2, a member of the sirtuin family, extended lifespan in budding yeast [68]. Sir-2.1 and $d$ Sir 2 are the homologs of S. cerevisiae SIR2 in C. elegans and Drosophila, respectively. Increased expression levels of Sir-2.1 and dSir2 extend the lifespan of worms and flies. However, the effect of Sir2 is variable because of differences in genetic background and the mutagenic effects of transgene insertions [69]. Further research revealed that the effects of increased dSir2 expression on lifespan in Drosophila are dosage-dependent. Significant lifespan extension is observed when $d$ Sir2 expression is induced between two- and five-fold [70]. This effect is tissue-specific, as overexpression of $d \operatorname{Sir} 2$ in the pan-neuronal cells or fat body extended lifespan, whereas induction in motoneuron or muscles did not [71].

$R p d 3$ is a zinc-dependent histone deacetylase in Drosophila and a homolog of mammal HDAC1. Reduction or inhibition of $r p d 3$ extends longevity, increases energy storage and downregulates gene expressions of the IIS pathway [72]. There is an overlap between $r p d 3$ and IIS longevity pathways, as mutations in $r p d 3$ and $d f o x o$ showed weakened stress resistance compared with rpd3 single mutant flies [72]. Lifespan extension in rpd3 mutant flies may overlap with the mechanism of extension seen in dietary restriction (DR). $d$ Sir2 has been implicated in mediating the response to DR in metazoans. Flies with double mutations in $r p d 3$ and $d S i r 2$ had a median lifespan shorter than control flies, while rpd3 mutants lived longer [73]. Continued exploration has found a potential interaction between $r p d 3$-mediated longevity and the protein synthesis regulator $4 E-B P$ (a downstream of the TOR signaling pathway), based on the reduced longevity for both rpd3 and $4 E-B P$ mutants compared to the single mutants of $r p d 3$ [74]. Therefore, $r p d 3$ is associated with the IIS, DR and TOR signaling pathways to promote longevity.

\section{Chromatin Alterations in Aging}

Changes in DNA and histone modifications are finally shown in chromatin changes. During aging, loss of histone and heterochromatin causes the chromatin structure to loosen, resulting in loss 
of transcriptional silencing. Retrotransposable elements are silenced by anchoring heterochromatin. The loss of heterochromatin with aging also leads to increased expression of otherwise silent retrotransposons [13]. The resulting transcripts from the retrotransposable elements are reverse-transcribed into cDNAs, which reinsert elsewhere into the genome of old cells, leading to genomic instability [75]. It was reported that HP1 (heterochromatin protein 1) destabilization was found in aged Drosophila, and overexpression of HP1 extended lifespan [76]. Deficiency of HP1 $\alpha$ in enterocytes (ECs) leads to intestinal stem cell (ISC) aging, implying the loss of heterochromatin stability, which may be the crucial mechanism for ISC aging [48]. It seems that keeping heterochromatin stable could promote longevity.

It was known that SWI/SNF, NuRD (nucleosome remodeling and deacetylase) and the polycomb system make a difference in chromatin regulation [77]. Polycomb complexes are associated with chromatin containing repressive marks and silent or low transcriptional states [78]. Studies have pointed to a genetic antagonism between the SWI/SNF complex and polycomb repressive complexes 1 and 2 (PRC1/2) in Drosophila. Deletion of the BAF ATPases catalytic subunit Smarca4 in mouse embryonic stem cells can cause a genome-wide increase in the localization of PRC1 and PRC2 and the abundance of H3K27me3, resulting in chromatin regulation [78]. The deficiency in CHD3, a subunit of the NuRD complex [79], elevated p53-dependent germline apoptosis, mainly due to the failure in the timely repair of double-stranded breaks, eventually leading to an increase in chromatin defects and apoptosis in worms [80]. In short, SWI/SNF contributes to the open chromatin state and active transcription; NuRD promotes the production of the repression of chromatin; and the polycomb complex promotes the formation of chromatin compression environments.

\section{Non-Coding RNAs in Invertebrates during Aging}

Non-coding RNAs (ncRNAs) comprise various RNA species, including microRNA (miRNA), tRNA-derived small RNA (tsRNA), ribosomal RNA (rRNA), piwi-interacting RNA (piRNA), circular RNA (circRNA), and lncRNA [81]. ncRNAs have a remarkable impact on gene expression and chromatin remodeling by binding to their targets [82]. Mostly, total miRNA and piRNA are gradually decreased during aging in C. elegans, whereas in contrast, tsRNA, rRNA and circRNA levels generally display age-dependent increases [81]. The genetic modulation of specific ncRNAs affects longevity and aging rates by modulating established aging-regulating protein factors [81]. Generally, miRNA affects the aging process by acting on specific genes and altering their expression. miRNAs specifically target the $3^{\prime}$-UTR of mRNAs to exert transcriptional repression. A highly conserved miRNA, miR-124, was significantly upregulated in APS-induced longevity of C. elegans by regulating ATF-6 (an endoplasmic reticulum stress-regulated transmembrane transcription factor) [83]. The specific overexpression of the miRNA let-7 in the Drosophila nervous system increased female median fly lifespan by $\sim 22 \%$ [84]. RNA polymerase III can generate non-coding RNAs, including tRNAs. A reduction in RNA polymerase III can extend lifespan in worms and flies [85]. Therefore, this sheds light on tRNAs' possible involvement in the aging process.

In animals, piwi-interacting RNAs (piRNAs) of 21-35 nucleotides in length silence transposable elements; nearly all animals rely on piRNAs to defend the germline genome from transposon expression [86]. Piwi proteins combine with pi-RNA to silence targets post-transcriptionally. In flies, piwi promote $\mathrm{H} 3 \mathrm{~K} 9$ methylation, a repressive chromatin mark, through the recruitment of Eggless (also known as dSetdb1) by the piwi-interacting mediator proteins Asterix and Panoramix [87]. Piwi can repress heterochromatin loss, age-related dysfunction and apoptosis in ISCs, subsequently maintaining somatic stem cell genomic integrity [88].

CircRNAs are stable because the lack of free $5^{\prime}$-and $3^{\prime}$-ends protects them against nuclease attack [89]. These circRNAs can function as microRNA sponges to regulate mRNA, ultimately changing gene expression [90]. The expression of circ_0005230 was elevated in human tumors and cholangiocarcinoma (CCA) cells, and it significantly facilitated cell growth, clone-forming ability and metastatic properties and inhibited cell apoptosis in CCA cells. Further study implies that circ_0005230 
could directly sponge miR-1238 and miR-1299 to exert its oncogenic function [91]. In humans, circRNA may also be involved in the regulation of ovarian function and aging by targeting certain miRNAs [92]. Therefore, specific circRNAs may function as anti-aging elements.

LncRNAs with a variable length spanning from $200 \mathrm{bp}$ up to several kilobases appear to be important for proper neurological functioning, with aberrant expression of lncRNAs leading to neurological disorders in Drosophila [93]. One study found that there is a high expression of the lncRNA fer1l4 in human tumor tissues. Moreover, GO enrichment analysis also revealed that fer1l4 may be involved in processes associated with tumorigenesis [94]. Recent research shows that lncRNAs are associated with organismal aging. The lncRNA tts-1 in C. elegans extends lifespan, respectively, in daf-2 (insulin/IGF-1 receptor) and clk-1 (mitochondrial gene) mutations by reducing ribosome levels in a way that promotes life extension [95]. Therefore, some lncRNAs regulate lifespan in classic signaling pathways such as IIS pathway.

\section{Targets for Pharmacological Manipulation}

Epigenetic markers have become particularly interesting because, in addition to acting as markers for the genetic regulation of aging, epigenetic mechanisms may be targets for drugs in aging and age-related diseases (Figure 4). Many drug trials have confirmed these proposals. Resveratrol, as an activator of Sir2/SIRT1 and AMPK, extends the lifespan of yeast [96], worms and fruit flies [97]. However, this lifespan-extension effect of resveratrol is abrogated by the SIR2 mutation [97,98]. Natural compounds, such as curcumin or alkylresorcinols, enhanced SIRT1 activity and extended the lifespan of Drosophila $[98,99]$. NAD ${ }^{+}$is a necessary cofactor for many metabolic pathways, such as glycolysis, fatty acid b-oxidation, and the TCA cycle. Also, $\mathrm{NAD}^{+}$is also a substrate of sirtuin. $\mathrm{NAD}^{+}$levels decline during aging across species $[100,101]$, and supplementation of $\mathrm{NAD}^{+}$extended the lifespan of worms, mice [102] and flies [103]. $\mathrm{NAD}^{+}$precursors include nicotinamide (NAM), nicotinic acid (NA), tryptophan (Trp), nicotinamide riboside (NR), and nicotinamide mononucleotide (NMN); changes in these substances also affect sirtuins and then lifespan [104]. Therefore, Sir2/SIRT1 could be a promising target for aging intervention.

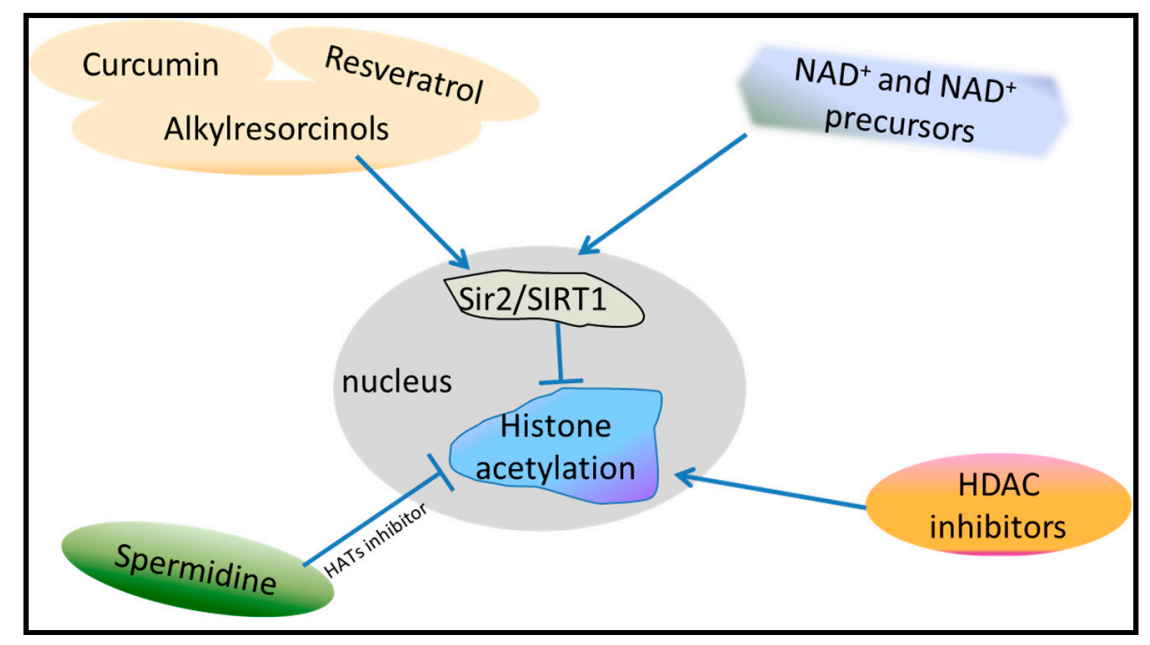

Figure 4. Epigenetic targets for pharmacological manipulation. Histone acetylation results in a more open chromatin state and greater access of DNA to transcription factors, leading to genome instability. Sir2/SIRT1 activators, such as curcumin, resveratrol and alkylresorcinols, can activate the sir2/SIRT1 activity to promote deacetylation. NAD+ and NAD+ precursors can also target sir2/SIRT1 to stimulate deacetylation. Spermidine, as a histone acetyltransferase (HAT) inhibitor, can suppress histone acetylation. Histone deacetylase (HDAC) inhibitors can promote histone acetylation.

With aging, transcription levels of genes involving biosynthetic, metabolic and immune functions decline [105]. Histone acetylation promotes transcription activation, and deacetylation inhibits 
transcription, suggesting that pharmacological intervention in the process could impact longevity. Thus, HDAC inhibitors can increase longevity by promoting gene transcription. Inhibitors such as sodium 4-phenylbutyrate (PBA), sodium butyrate (SB), trichostatin A (TSA), and suberoylanilide hydroxamic acid (SAHA) affect several pathways involved in the regulation of these gene expression patterns associated with healthy aging [106]. Metformin, the first drug chosen to be tested in a clinical trial aimed at targeting the biology of aging per se, may exert its anti-aging effect by acting on H3K27me3 [55].

Spermidine, a naturally occurring polyamine, directly inhibits HATs, maintaining histone H3 in a hypoacetylated state in human cells. This altered acetylation status leads to significant upregulation of various autophagy-related transcripts, triggering autophagy in yeast, flies, and human cells, thereby enhancing longevity [107]. Spermidine can also block the age-related changes of cardiac cell composition and function, enhance diastolic function without affecting systemic blood pressure, and extend lifespan in an autophagy-dependent manner [108]. Spermidine or similar compounds related to HATs or autophagy could be good candidates to extend lifespan.

It is expected that drugs targeting epigenetic marks are the most promising for aging intervention.

\section{Crosstalk between Epigenetic Marks}

Epigenetic markers are involved in many physiological processes, and their interaction makes these processes more complex. It was shown that there was an inverse correlation between DNA methylation and histone H3K4 methylation in human cells [109]. Subsequently, genome-wide research found that DNA methylation could discriminate promoters from enhancers through H3K4me1-H3K4me3 in the seesaw mechanism [110], suggesting that the balance of seesaw might be used to determine whether the body is in a normal state.

In many organisms, small RNAs modify chromatin via RNA interference pathways [111]. RNAi can produce long-term heritable responses that affect progeny [112]. In C. elegans, both exogenous and endogenous siRNAs can direct histone H3K27 methylation at targeted loci through the Nrde (nuclear RNAi defective) pathway, resulting in H3K27me3 status inheritance by progeny for multiple generations [113]. The induction of RNAi in met-2 (H3K9 methylation enzyme) mutant worms resulted in the transgenerational barrier being broken, while RNAi was stably inherited transgenerationally; consequently, the progeny become progressively sterile due to the accumulation of small RNAs coupled by defective H3K9 methylation [114]. Therefore, ncRNA together with methylation could modulate transgenerational inheritance.

In the Drosophila brain, miR-34 becomes upregulated in an age-associated manner and is functionally required for lifespan extension, whereas mir-34 loss was shown to accelerate brain aging and degeneration and a decline in survival [115]. A more recent study revealed that miR-34 repressed the translation of $\mathrm{Pcl}$ and $\mathrm{Su}(\mathrm{z}) 12$ (two components of PRC2) transcripts, resulting in a reduction of PRC2 activity and less H3K27me3, promoting healthy aging [116]. Epigenetic marks' interaction also exists in age-related diseases. In colon cancer cells, lncRNA CCAT2 acts as a negative regulator of miRNA-145 biogenesis, implying a novel mechanism of lncRNA-miRNA crosstalk [117].

There is also a crosstalk between histone deacetylase inhibitors and H3K4 methylation marks in prostate cancer cells [118]. It was reported that $\mathrm{H} 3 \mathrm{~K} 9 \mathrm{me} 3$ and DNA methylations interact with each other, probably through HP1 [119]. In addition, enhance RNA (eRNA) is one of the non-coding RNA molecules [120], which can bind CBP at enhancers and stimulate histone acetylation and transcription of target genes [121]. The crosstalk between epigenetic marks is even more complex than that described above, thus making the aging mechanism more compelling.

\section{Conclusions}

Epigenetic alteration involves changes in DNA methylation patterns, post-translational modification of histone, chromatin remodeling and non-coding RNA interference. These processes are each associated with the aging of D. melanogaster and C. elegans. However, we believe that the 
epigenetic landscape may be further complicated beyond the description above due to the crosstalk between epigenetic mechanisms. Understanding the epigenetic changes in the aging process can advance our knowledge of the mechanisms of aging. Drug research in epigenetics will be a powerful intervention in aging. A longer and healthier lifespan for humans could be achieved by leveraging the powerful genetic tools available for simple invertebrate models, in order to aid our understanding of aging mechanisms in the less tractable human system.

Author Contributions: G.Y. and M.Y. structured the text and content. G.Y. and Q.W. reviewed the literature and provided intellectual contributions. Y.G. and M.C. generated the figures. G.Y., Q.W. and M.Y. wrote the manuscript. All of the authors edited and approved the final version of the manuscript.

Funding: This work was supported by The National Natural Science Foundation of China (31771338).

Acknowledgments: We thank all lab members for invaluable comments on the manuscript and Julian Dow for comments and proofreading.

Conflicts of Interest: The authors declare no conflict of interest.

\begin{tabular}{|c|c|}
\hline $5 \mathrm{mC}$ & 5-methylcytosine \\
\hline $6 \mathrm{~mA}$ & N6-methyladenine \\
\hline Acetyl-coA & Acetyl coenzyme A \\
\hline AMPK & Adenosine $5^{\prime}$-monophosphate (AMP)-activated protein kinase \\
\hline ATPCL & ATP citrate lyase \\
\hline CpG & Cytosine Phosphate guanine \\
\hline DAMT & DNA adenine methyltransferase \\
\hline DMAD & DNA 6ma demethylase \\
\hline DNMT & DNA methyltransferase \\
\hline DR & Dietary restriction \\
\hline H3k27me3 & Trimethylation of lysine 27 on histone $\mathrm{H} 3$ protein subunit \\
\hline H3k36me3 & Trimethylation of lysine 36 on histone $\mathrm{H} 3$ protein subunit \\
\hline H3k4me2 & Dimethylation of lysine 4 on histone $\mathrm{H} 3$ protein subunit \\
\hline $\mathrm{H} 3 \mathrm{k} 4 \mathrm{me} 3$ & Trimethylation of lysine 4 on histone $\mathrm{H} 3$ protein subunit \\
\hline H3k9ac & Acetylation of lysine 4 on histone $\mathrm{H} 3$ protein subunit \\
\hline H3k9me3 & Trimethylation of lysine 9 on histone $\mathrm{H} 3$ protein subunit \\
\hline HAT & Histone acetyltransferase \\
\hline HDAC & Histone deacetylase \\
\hline $\mathrm{HDM} / \mathrm{KDM}$ & Histone demethylase \\
\hline HMT/KMT & Histone methyltransferase \\
\hline HP1 & Heterochromatin protein 1 \\
\hline IGF-1 & Insulin-like growth factor -1 \\
\hline IIS & Insulin/IGF-1 signaling pathway \\
\hline ISC & Intestinal stem cell \\
\hline MUFA & Mono-unsaturated fatty acid \\
\hline NAD+ & Nicotinamide adenine dinucleotide \\
\hline NuRD & Nucleosome remodeling and deacetylase \\
\hline PRC2 & Polycomb repressive complex 2 \\
\hline SWI/SNF & Switch/sucrose non-fermenting \\
\hline TCA & Tricarboxylic acid cycle \\
\hline TET & Ten-eleven translocation \\
\hline TOR & Target of rapamycin \\
\hline
\end{tabular}

\section{References}

1. De Cabo, R.; Carmona-Gutierrez, D.; Bernier, M.; Hall, M.N.; Madeo, F. The search for antiaging interventions: From elixirs to fasting regimens. Cell 2014, 157, 1515-1526. [CrossRef] [PubMed]

2. Zhang, R.; Chen, H.Z.; Liu, D.P. The Four Layers of Aging. Cell Syst. 2015, 1, 180-186. [CrossRef] [PubMed] 
3. Kenyon, C.J. The genetics of ageing. Nature 2010, 464, 504-512. [CrossRef] [PubMed]

4. Lopez-Otin, C.; Blasco, M.A.; Partridge, L.; Serrano, M.; Kroemer, G. The hallmarks of aging. Cell 2013, 153, 1194-1217. [CrossRef] [PubMed]

5. Feser, J.; Truong, D.; Das, C.; Carson, J.J.; Kieft, J.; Harkness, T.; Tyler, J.K. Elevated histone expression promotes life span extension. Mol. Cell 2010, 39, 724-735. [CrossRef]

6. Jung, M.; Pfeifer, G.P. Aging and DNA methylation. BMC Biol. 2015, 13, 7. [CrossRef] [PubMed]

7. Hou, Q.; Ruan, H.; Gilbert, J.; Wang, G.; Ma, Q.; Yao, W.D.; Man, H.Y. MicroRNA miR124 is required for the expression of homeostatic synaptic plasticity. Nat. Commun. 2015, 6. [CrossRef]

8. Harman, M.F.; Martin, M.G. Epigenetic mechanisms related to cognitive decline during aging. J. Neurosci. Res. 2019. [CrossRef]

9. Morris, B.J.; Willcox, B.J.; Donlon, T.A. Genetic and epigenetic regulation of human aging and longevity. BBA Mol. Basis Dis. 2019, 1865, 1718-1744. [CrossRef]

10. Piper, M.D.W.; Partridge, L. Drosophila as a model for ageing. Biochim. Biophys. Acta Mol. Basis Dis. 2018, 1864, 2707-2717. [CrossRef]

11. Gems, D.; Partridge, L. Genetics of longevity in model organisms: Debates and paradigm shifts. Annu. Rev. Physiol. 2013, 75, 621-644. [CrossRef] [PubMed]

12. Goll, M.G.; Bestor, T.H. Eukaryotic cytosine methyltransferases. Annu. Rev. Biochem. 2005, 74, 481-514. [CrossRef] [PubMed]

13. Pal, S.; Tyler, J.K. Epigenetics and aging. Sci. Adv. 2016, 2. [CrossRef] [PubMed]

14. Zagkos, L.; Auley, M.M.; Roberts, J.; Kavallaris, N.I. Mathematical models of DNA methylation dynamics: Implications for health and ageing. J. Theor. Biol. 2019, 462, 184-193. [CrossRef] [PubMed]

15. Morgan, A.E.; Davies, T.J.; Mc Auley, M.T. The role of DNA methylation in ageing and cancer. Proc. Nutr. Soc. 2018, 77, 412-422. [CrossRef]

16. Gensous, N.; Bacalini, M.G.; Franceschi, C.; Meskers, C.G.M.; Maier, A.B.; Garagnani, P. Age-related DNA methylation changes: Potential impact on skeletal muscle aging in humans. Front. Physiol. 2019, 10. [CrossRef]

17. Kohli, R.M.; Zhang, Y. TET enzymes, TDG and the dynamics of DNA demethylation. Nature 2013, 502, 472-479. [CrossRef]

18. Wenzel, D.; Palladino, F.; Jedrusik-Bode, M. Epigenetics in C. elegans: Facts and challenges. Genesis 2011, 49, 647-661. [CrossRef]

19. Capuano, F.; Mulleder, M.; Kok, R.; Blom, H.J.; Ralser, M. Cytosine DNA methylation is found in Drosophila melanogaster but absent in Saccharomyces cerevisiae, Schizosaccharomyces pombe, and other yeast species. Anal. Chem. 2014, 86, 3697-3702. [CrossRef]

20. Lian, T.; Gaur, U.; Wu, Q.I.; Tu, J.; Sun, B.; Yang, D.; Fan, X.; Mao, X.; Yang, M. DNA methylation is not involved in dietary restriction induced lifespan extension in adult Drosophila. Genet. Res. 2018, 100. [CrossRef]

21. Lin, M.J.; Tang, L.Y.; Reddy, M.N.; Shen, C.K. DNA methyltransferase gene dDnmt2 and longevity of Drosophila. J. Biol. Chem. 2005, 280, 861-864. [CrossRef] [PubMed]

22. Greer, E.L.; Blanco, M.A.; Gu, L.; Sendinc, E.; Liu, J.; Aristizabal-Corrales, D.; Hsu, C.H.; Aravind, L.; He, C.; Shi, Y. DNA methylation on N6-Adenine in C. elegans. Cell 2015, 161, 868-878. [CrossRef] [PubMed]

23. Zhang, G.; Huang, H.; Liu, D.; Cheng, Y.; Liu, X.; Zhang, W.; Yin, R.; Zhang, D.; Zhang, P.; Liu, J.; et al. N6-methyladenine DNA modification in Drosophila. Cell 2015, 161, 893-906. [CrossRef] [PubMed]

24. Luo, G.Z.; Blanco, M.A.; Greer, E.L.; He, C.; Shi, Y. DNA N(6)-methyladenine: A new epigenetic mark in eukaryotes? Nat. Rev. Mol. Cell Biol. 2015, 16, 705-710. [CrossRef] [PubMed]

25. Greer, E.L.; Beese-Sims, S.E.; Brookes, E.; Spadafora, R.; Zhu, Y.; Rothbart, S.B.; Aristizabal-Corrales, D.; Chen, S.; Badeaux, A.I.; Jin, Q.; et al. A histone methylation network regulates transgenerational epigenetic memory in C. elegans. Cell Rep. 2014, 7, 113-126. [CrossRef] [PubMed]

26. Yao, B.; Li, Y.; Wang, Z.; Chen, L.; Poidevin, M.; Zhang, C.; Lin, L.; Wang, F.; Bao, H.; Jiao, B.; et al. Active $\mathrm{N}(6)$-Methyladenine demethylation by DMAD regulates gene expression by coordinating with polycomb protein in neurons. Mol. Cell 2018, 71, 848-857. [CrossRef] [PubMed]

27. Sen, P.; Shah, P.P.; Nativio, R.; Berger, S.L. Epigenetic mechanisms of longevity and aging. Cell 2016, 166, 822-839. [CrossRef] [PubMed]

28. Rivera, C.M.; Ren, B. Mapping human epigenomes. Cell 2013, 155, 39-55. [CrossRef] 
29. Wang, Y.; Yuan, Q.; Xie, L. Histone modifications in aging: The underlying mechanisms and implications. Curr. Stem Cell Res. 2018, 13, 125-135. [CrossRef]

30. Barski, A.; Cuddapah, S.; Cui, K.; Roh, T.Y.; Schones, D.E.; Wang, Z.; Wei, G.; Chepelev, I.; Zhao, K. High-resolution profiling of histone methylations in the human genome. Cell 2007, 129, 823-837. [CrossRef]

31. Pu, M.; Wang, M.; Wang, W.; Velayudhan, S.S.; Lee, S.S. Unique patterns of trimethylation of histone H3 lysine 4 are prone to changes during aging in Caenorhabditis elegans somatic cells. PLoS Genet. 2018, 14. [CrossRef] [PubMed]

32. Han, S.; Brunet, A. Histone methylation makes its mark on longevity. Trends Cell Biol. 2012, 22, 42-49. [CrossRef] [PubMed]

33. Greer, E.L.; Maures, T.J.; Hauswirth, A.G.; Green, E.M.; Leeman, D.S.; Maro, G.S.; Han, S.; Banko, M.R.; Gozani, O.; Brunet, A. Members of the H3K4 trimethylation complex regulate lifespan in a germline-dependent manner in C. elegans. Nature 2010, 466, 383-387. [CrossRef] [PubMed]

34. Greer, E.L.; Maures, T.J.; Ucar, D.; Hauswirth, A.G.; Mancini, E.; Lim, J.P.; Benayoun, B.A.; Shi, Y.; Brunet, A. Transgenerational epigenetic inheritance of longevity in Caenorhabditis elegans. Nature 2011, 479, 365-371. [CrossRef] [PubMed]

35. Ma, C.; Niu, R.; Huang, T.; Shao, L.W.; Peng, Y.; Ding, W.; Wang, Y.; Jia, G.; He, C.; Li, C.Y.; et al. N6-methyldeoxyadenine is a transgenerational epigenetic signal for mitochondrial stress adaptation. Nat. Cell Biol. 2019, 21, 319-327. [CrossRef] [PubMed]

36. Han, S.; Schroeder, E.A.; Silva-Garcia, C.G.; Hebestreit, K.; Mair, W.B.; Brunet, A. Mono-unsaturated fatty acids link H3K4me3 modifiers to C. elegans lifespan. Nature 2017, 544, 185-190. [CrossRef]

37. Laplante, M.; Sabatini, D.M. mTOR signaling in growth control and disease. Cell 2012, 149, $274-293$. [CrossRef] [PubMed]

38. Liu, M.; Barnes, V.L.; Pile, L.A. Disruption of methionine metabolism in Drosophila melanogaster impacts histone methylation and results in loss of viability. G3 (Bethesda) 2015, 6, 121-132. [CrossRef]

39. Li, L.; Greer, C.; Eisenman, R.N.; Secombe, J. Essential functions of the histone demethylase lid. Plos Genet. 2010, 6. [CrossRef]

40. Nan, Z.; Yang, W.; Lyu, J.; Wang, F.; Deng, Q.; Xi, Y.; Yang, X.; Ge, W. Drosophila Hcf regulates the Hippo signaling pathway via association with the histone H3K4 methyltransferase Trr. Biochem. J. 2019, 476, 759-768. [CrossRef]

41. Zamurrad, S.; Hatch, H.A.M.; Drelon, C.; Belalcazar, H.M.; Secombe, J. A Drosophila model of intellectual disability caused by mutations in the histone demethylase KDM5. Cell Rep. 2018, 22, 2359-2369. [CrossRef] [PubMed]

42. Vallianatos, C.N.; Iwase, S. Disrupted intricacy of histone H3K4 methylation in neurodevelopmental disorders. Epigenomics 2015, 7, 503-519. [CrossRef] [PubMed]

43. Chen, K.; Luan, X.; Liu, Q.; Wang, J.; Chang, X.; Snijders, A.M.; Mao, J.H.; Secombe, J.; Dan, Z.; Chen, J.H.; et al. Drosophila histone demethylase KDM5 regulates social behavior through immune control and gut microbiota maintenance. Cell Host Microbe. 2019, 25, 537-552. [CrossRef] [PubMed]

44. Yang, B.; Xu, X.; Russell, L.; Sullenberger, M.T.; Yanowitz, J.L.; Maine, E.M. A DNA repair protein and histone methyltransferase interact to promote genome stability in the Caenorhabditis elegans germ line. PLoS Genet. 2019, 15. [CrossRef] [PubMed]

45. Myers, T.R.; Amendola, P.G.; Lussi, Y.C.; Salcini, A.E. JMJD-1.2 controls multiple histone post-translational modifications in germ cells and protects the genome from replication stress. Sci Rep. 2018, 8. [CrossRef] [PubMed]

46. Lachner, M.; O'Carroll, D.; Rea, S.; Mechtler, K.; Jenuwein, T. Methylation of histone H3 lysine 9 creates a binding site for HP1 proteins. Nature 2001, 410, 116-120. [CrossRef]

47. Wood, J.G.; Hillenmeyer, S.; Lawrence, C.; Chang, C.; Hosier, S.; Lightfoot, W.; Mukherjee, E.; Jiang, N.; Schorl, C.; Brodsky, A.S.; et al. Chromatin remodeling in the aging genome of Drosophila. Aging Cell 2010, 9 , 971-978. [CrossRef]

48. Jeon, H.J.; Kim, Y.S.; Kim, J.G.; Heo, K.; Pyo, J.H.; Yamaguchi, M.; Park, J.S.; Yoo, M.A. Effect of heterochromatin stability on intestinal stem cell aging in Drosophila. Mech. Ageing Dev. 2018, 173, 50-60. [CrossRef]

49. Tsurumi, A.; Xue, S.; Zhang, L.; Li, J.; Li, W.X. Genome-wide Kdm4 histone demethylase transcriptional regulation in Drosophila. Mol. Genet. Genom. 2019. [CrossRef] 
50. Ma, Z.; Wang, H.; Cai, Y.; Wang, H.; Niu, K.; Wu, X.; Ma, H.; Yang, Y.; Tong, W.; Liu, F.; et al. Epigenetic drift of H3K27me3 in aging links glycolysis to healthy longevity in Drosophila. Elife 2018, 7. [CrossRef]

51. Siebold, A.P.; Banerjee, R.; Tie, F.; Kiss, D.L.; Moskowitz, J.; Harte, P.J. Polycomb Repressive Complex 2 and Trithorax modulate Drosophila longevity and stress resistance. Proc. Natl. Acad. Sci. USA 2010, 107, 169-174. [CrossRef] [PubMed]

52. Lopez-Otin, C.; Galluzzi, L.; Freije, J.M.P.; Madeo, F.; Kroemer, G. Metabolic Control of Longevity. Cell 2016, 166, 802-821. [CrossRef] [PubMed]

53. Ahringer, J.; Gasser, S.M. Repressive Chromatin in Caenorhabditis elegans: Establishment, Composition, and Function. Genetics 2018, 208, 491-511. [CrossRef] [PubMed]

54. Ni, Z.; Ebata, A.; Alipanahiramandi, E.; Lee, S.S. Two SET domain containing genes link epigenetic changes and aging in Caenorhabditis elegans. Aging Cell 2012, 11, 315-325. [CrossRef] [PubMed]

55. Cuyas, E.; Verdura, S.; Llorach-Pares, L.; Fernandez-Arroyo, S.; Luciano-Mateo, F.; Cabre, N.; Stursa, J.; Werner, L.; Martin-Castillo, B.; Viollet, B.; et al. Metformin directly targets the H3K27me3 demethylase KDM6A/UTX. Aging Cell 2018. [CrossRef] [PubMed]

56. Maures, T.J.; Greer, E.L.; Hauswirth, A.G.; Brunet, A. The H3K27 demethylase UTX-1 regulates C. elegans lifespan in a germline-independent, insulin-dependent manner. Aging Cell 2011, 10, 980-990. [CrossRef]

57. Jin, C.; Li, J.; Green, C.D.; Yu, X.; Tang, X.; Han, D.; Xian, B.; Wang, D.; Huang, X.; Cao, X.; et al. Histone demethylase UTX-1 regulates C. elegans life span by targeting the insulin/IGF-1 signaling pathway. Cell Metab. 2011, 14, 161-172. [CrossRef] [PubMed]

58. Sen, P.; Dang, W.; Donahue, G.; Dai, J.; Dorsey, J.; Cao, X.; Liu, W.; Cao, K.; Perry, R.; Lee, J.Y.; et al. H3K36 methylation promotes longevity by enhancing transcriptional fidelity. Genes Dev. 2015, 29, 1362-1376. [CrossRef]

59. Pu, M.; Ni, Z.; Wang, M.; Wang, X.; Wood, J.G.; Helfand, S.L.; Yu, H.; Lee, S.S. Trimethylation of Lys36 on H3 restricts gene expression change during aging and impacts life span. Genes Dev. 2015, 29, 718-731. [CrossRef]

60. Li, J.; Ahn, J.H.; Wang, G.G. Understanding histone H3 lysine 36 methylation and its deregulation in disease. Cell Mol. Life Sci. 2019, 76, 2899-2916. [CrossRef]

61. McDaniel, S.L.; Strahl, B.D. Shaping the cellular landscape with Set2/SETD2 methylation. Cell Mol. Life Sci. 2017, 74, 3317-3334. [CrossRef] [PubMed]

62. Su, L.; Li, H.; Huang, C.; Zhao, T.; Zhang, Y.; Ba, X.; Li, Z.; Zhang, Y.; Huang, B.; Lu, J.; et al. Muscle-Specific Histone H3K36 Dimethyltransferase SET-18 Shortens Lifespan of Caenorhabditis elegans by Repressing daf-16a Expression. Cell Rep. 2018, 22, 2716-2729. [CrossRef] [PubMed]

63. Peleg, S.; Feller, C.; Forne, I.; Schiller, E.; Sevin, D.C.; Schauer, T.; Regnard, C.; Straub, T.; Prestel, M.; Klima, C.; et al. Life span extension by targeting a link between metabolism and histone acetylation in Drosophila. EMBO Rep. 2016, 17, 455-469. [CrossRef] [PubMed]

64. Zhou, L.; He, B.; Deng, J.; Pang, S.; Tang, H. Histone acetylation promotes long-lasting defense responses and longevity following early life heat stress. PLoS Genet. 2019, 15. [CrossRef] [PubMed]

65. Peleg, S.; Feller, C.; Ladurner, A.G.; Imhof, A. The Metabolic Impact on Histone Acetylation and Transcription in Ageing. Trends Biochem. Sci. 2016, 41, 700-711. [CrossRef] [PubMed]

66. Graff, J.; Tsai, L.H. Histone acetylation: Molecular mnemonics on the chromatin. Nat. Rev. Neurosci 2013, 14, 97-111. [CrossRef] [PubMed]

67. Li, K.L.; Zhang, L.; Yang, X.M.; Fang, Q.; Yin, X.F.; Wei, H.M.; Zhou, T.; Li, Y.B.; Chen, X.L.; Tang, F.; et al. Histone acetyltransferase CBP-related H3K23 acetylation contributes to courtship learning in Drosophila. Bmc Dev. Biol. 2018. [CrossRef]

68. Wierman, M.B.; Smith, J.S. Yeast sirtuins and the regulation of aging. Fems Yeast Res. 2014, 14, 73-88. [CrossRef] [PubMed]

69. Burnett, C.; Valentini, S.; Cabreiro, F.; Goss, M.; Somogyvari, M.; Piper, M.D.; Hoddinott, M.; Sutphin, G.L.; Leko, V.; McElwee, J.J.; et al. Absence of effects of Sir2 overexpression on lifespan in C. elegans and Drosophila. Nature 2011, 477, 482-485. [CrossRef] [PubMed]

70. Whitaker, R.; Faulkner, S.; Miyokawa, R.; Burhenn, L.; Henriksen, M.; Wood, J.G.; Helfand, S.L. Increased expression of Drosophila Sir2 extends life span in a dose-dependent manner. Aging (Albany Ny) 2013, 5, 682-691. [CrossRef]

71. Lee, S.H.; Lee, J.H.; Lee, H.Y.; Min, K.J. Sirtuin signaling in cellular senescence and aging. BMB Rep. 2019, 52, 24-34. [CrossRef] [PubMed] 
72. Woods, J.K.; Ziafazeli, T.; Rogina, B. Rpd3 interacts with insulin signaling in Drosophila longevity extension. Aging (Albany Ny) 2016, 8, 3028-3044. [CrossRef] [PubMed]

73. Rogina, B.; Helfand, S.L. Sir2 mediates longevity in the fly through a pathway related to calorie restriction. Proc. Natl. Acad. Sci. USA 2004, 101, 15998-16003. [CrossRef]

74. Frankel, S.; Woods, J.; Ziafazeli, T.; Rogina, B. RPD3 histone deacetylase and nutrition have distinct but interacting effects on Drosophila longevity. Aging (Albany Ny) 2015, 7, 1112-1129. [CrossRef] [PubMed]

75. Maxwell, P.H.; Burhans, W.C.; Curcio, M.J. Retrotransposition is associated with genome instability during chronological aging. Proc. Natl. Acad. Sci. USA 2011, 108, 20376-20381. [CrossRef] [PubMed]

76. Larson, K.; Yan, S.J.; Tsurumi, A.; Liu, J.; Zhou, J.; Gaur, K.; Guo, D.; Eickbush, T.H.; Li, W.X. Heterochromatin formation promotes longevity and represses ribosomal RNA synthesis. PLoS Genet. 2012. [CrossRef] [PubMed]

77. Bracken, A.P.; Brien, G.L.; Verrijzer, C.P. Dangerous liaisons: Interplay between SWI/SNF, NuRD, and Polycomb in chromatin regulation and cancer. Genes Dev. 2019, 33, 15-16. [CrossRef]

78. Stanton, B.Z.; Hodges, C.; Calarco, J.P.; Braun, S.M.G.; Ku, W.L.; Kadoch, C.; Zhao, K.; Crabtree, G.R. Smarca4 ATPase mutations disrupt direct eviction of PRC1 from chromatin. Nat. Genet. 2016, 49, 282-288. [CrossRef]

79. Torchy, M.P.; Hamiche, A.; Klaholz, B.P. Structure and function insights into the NuRD chromatin remodeling complex. Cell Mol. Life Sci. 2015, 72, 2491-2507. [CrossRef]

80. Turcotte, C.A.; Sloat, S.A.; Rigothi, J.A.; Rosenkranse, E.; Northrup, A.L.; Andrews, N.P.; Checchi, P.M. Maintenance of genome integrity by Mi2 homologs CHD-3 and LET-418 in Caenorhabditis elegans. Genetics 2018, 208, 991-1007. [CrossRef]

81. Kim, S.S.; Lee, S.V. Non-Coding RNAs in Caenorhabditis elegans Aging. Mol. Cells 2019, 42, 379-385. [PubMed]

82. Cech, T.R.; Steitz, J.A. The noncoding RNA revolution-trashing old rules to forge new ones. Cell 2014, 157, 77-94. [CrossRef] [PubMed]

83. Wang, N.; Liu, J.; Xie, F.; Gao, X.; Ye, J.H.; Sun, L.Y.; Wei, R.; Ai, J. miR-124/ATF-6, a novel lifespan extension pathway of Astragalus polysaccharide in Caenorhabditis elegans. J. Cell Biochem. 2015, 116, $242-251$. [CrossRef] [PubMed]

84. Gendron, C.M.; Pletcher, S.D. MicroRNAs mir-184 and let-7 alter Drosophila metabolism and longevity. Aging Cell 2017, 16, 1434-1438. [CrossRef] [PubMed]

85. Filer, D.; Thompson, M.A.; Takhaveev, V.; Dobson, A.J.; Kotronaki, I.; Green, J.W.M.; Heinemann, M.; Tullet, J.M.A.; Alic, N. RNA polymerase III limits longevity downstream of TORC1. Nature 2017, 552, $263-267$. [CrossRef] [PubMed]

86. Ozata, D.M.; Gainetdinov, I.; Zoch, A.; O'Carroll, D.; Zamore, P.D. PIWI-interacting RNAs: Small RNAs with big functions. Nat. Rev. Genet. 2019, 20, 89-108. [CrossRef]

87. Yu, Y.; Gu, J.; Jin, Y.; Luo, Y.; Preall, J.B.; Ma, J.; Czech, B.; Hannon, G.J. Panoramix enforces piRNA-dependent cotranscriptional silencing. Science 2015, 350, 339-342. [CrossRef] [PubMed]

88. Sousa-Victor, P.; Ayyaz, A.; Hayashi, R.; Qi, Y.; Madden, D.T.; Lunyak, V.V.; Jasper, H. Piwi Is Required to Limit Exhaustion of Aging Somatic Stem Cells. Cell Rep. 2017, 20, 2527-2537. [CrossRef]

89. Fischer, J.W.; Leung, A.K.L. CircRNAs: A regulator of cellular stress. Crit Rev. Biochem. Mol. Biol 2017, 52, 220-233. [CrossRef]

90. Yang, D.; Yang, K.; Yang, M. Circular RNA in Aging and Age-Related Diseases. Adv. Exp. Med. Biol. 2018, 1086, 17-35.

91. Xu, Y.; Yao, Y.; Liu, Y.; Wang, Z.; Hu, Z.; Su, Z.; Li, C.; Wang, H.; Jiang, X.; Kang, P.; et al. Elevation of circular RNA circ_0005230 facilitates cell growth and metastasis via sponging miR-1238 and miR-1299 in cholangiocarcinoma. Aging (Albany Ny) 2019, 11, 1907-1917. [CrossRef] [PubMed]

92. Cai, H.; Li, Y.; Li, H.; Niringiyumukiza, J.D.; Zhang, M.; Chen, L.; Chen, G.; Xiang, W. Identification and characterization of human ovary-derived circular RNAs and their potential roles in ovarian aging. Aging (Albany Ny) 2018, 10, 2511-2534. [CrossRef] [PubMed]

93. Lo Piccolo, L. Drosophila as a Model to Gain Insight into the Role of lncRNAs in Neurological Disorders. Drosoph. Models for Hum. Dis. 2018, 1076, 119-146.

94. You, Z.; Ge, A.; Pang, D. Long noncoding RNA FER1L4 acts as an oncogenic driver in human pan-cancer. J. Cell. Physiol. 2019. [CrossRef] [PubMed] 
95. Essers, P.B.; Nonnekens, J.; Goos, Y.J.; Betist, M.C.; Viester, M.D.; Mossink, B.; Lansu, N.; Korswagen, H.C.; Jelier, R.; Brenkman, A.B.; et al. A Long Noncoding RNA on the Ribosome Is Required for Lifespan Extension. Cell Rep. 2015, 10, 339-345. [CrossRef] [PubMed]

96. Howitz, K.T.; Bitterman, K.J.; Cohen, H.Y.; Lamming, D.W.; Lavu, S.; Wood, J.G.; Zipkin, R.E.; Chung, P.; Kisielewski, A.; Zhang, L.-L.; et al. Small molecule activators of sirtuins extend Saccharomyces cerevisiae lifespan. Nature 2003, 425, 191-196. [CrossRef] [PubMed]

97. Wood, J.G.; Rogina, B.; Lavu, S.; Howitz, K.; Helfand, S.L.; Tatar, M.; Sinclair, D. Sirtuin activators mimic caloric restriction and delay ageing in metazoans. Nature 2004, 430, 686-689. [CrossRef] [PubMed]

98. Kayashima, Y.; Katayanagi, Y.; Tanaka, K.; Fukutomi, R.; Hiramoto, S.; Imai, S. Alkylresorcinols activate SIRT1 and delay ageing in Drosophila melanogaster. Sci. Rep. 2017, 7, 43679. [CrossRef] [PubMed]

99. Sun, Q.; Jia, N.; Wang, W.; Jin, H.; Xu, J.; Hu, H. Activation of SIRT1 by curcumin blocks the neurotoxicity of amyloid-beta25-35 in rat cortical neurons. Biochem. Biophys. Res. Commun. 2014, 448, 89-94. [CrossRef]

100. Fang, E.F.; Scheibye-Knudsen, M.; Brace, L.E.; Kassahun, H.; SenGupta, T.; Nilsen, H.; Mitchell, J.R.; Croteau, D.L.; Bohr, V.A. Defective mitophagy in XPA via PARP-1 hyperactivation and NAD+/SIRT1 reduction. Cell 2014, 157, 882-896. [CrossRef]

101. Zhu, X.H.; Lu, M.; Lee, B.Y.; Ugurbil, K.; Chen, W. In vivo NAD assay reveals the intracellular NAD contents and redox state in healthy human brain and their age dependences. Proc. Natl. Acad. Sci. USA 2015, 112, 2876-2881. [CrossRef] [PubMed]

102. Fang, E.F.; Kassahun, H.; Croteau, D.L.; Scheibye-Knudsen, M.; Marosi, K.; Lu, H.; Shamanna, R.A.; Kalyanasundaram, S.; Bollineni, R.C.; Wilson, M.A.; et al. NAD(+) Replenishment improves lifespan and healthspan in ataxia telangiectasia models via mitophagy and DNA repair. Cell Metab. 2016, 24, 566-581. [CrossRef] [PubMed]

103. Bradshaw, P.C. Cytoplasmic and mitochondrial NADPH-coupled redox systems in the regulation of aging. Nutrients 2019, 11. [CrossRef] [PubMed]

104. Mendelsohn, A.R.; Larrick, J.W. The NAD+/PARP1/SIRT1 Axis in Aging. Rejuvenation Res. 2017, $20,244-247$. [CrossRef] [PubMed]

105. Seroude, L.; Brummel, T.; Kapahi, P.; Benzer, S. Spatio-temporal analysis of gene expression during aging in Drosophila melanogaster. Aging Cell 2002, 1, 47-56. [CrossRef] [PubMed]

106. Pasyukova, E.G.; Vaiserman, A.M. HDAC inhibitors: A new promising drug class in anti-aging research. Mech. Ageing Dev. 2017, 166, 6-15. [CrossRef]

107. Eisenberg, T.; Knauer, H.; Schauer, A.; Buttner, S.; Ruckenstuhl, C.; Carmona-Gutierrez, D.; Ring, J.; Schroeder, S.; Magnes, C.; Antonacci, L.; et al. Induction of autophagy by spermidine promotes longevity. Nat. Cell Biol. 2009, 11, 1305-1314. [CrossRef]

108. Eisenberg, T.; Abdellatif, M.; Schroeder, S.; Primessnig, U.; Stekovic, S.; Pendl, T.; Harger, A.; Schipke, J.; Zimmermann, A.; Schmidt, A.; et al. Cardioprotection and lifespan extension by the natural polyamine spermidine. Nat. Med. 2016, 22, 1428-1438. [CrossRef]

109. Weber, M.; Hellmann, I.; Stadler, M.B.; Ramos, L.; Paabo, S.; Rebhan, M.; Schubeler, D. Distribution, silencing potential and evolutionary impact of promoter DNA methylation in the human genome. Nat. Genet. 2007, 39, 457-466. [CrossRef]

110. Sharifi-Zarchi, A.; Gerovska, D.; Adachi, K.; Totonchi, M.; Pezeshk, H.; Taft, R.J.; Scholer, H.R.; Chitsaz, H.; Sadeghi, M.; Baharvand, H.; et al. DNA methylation regulates discrimination of enhancers from promoters through a H3K4me1-H3K4me3 seesaw mechanism. Bmc Genom. 2017, 18, 964. [CrossRef]

111. Holoch, D.; Moazed, D. RNA-mediated epigenetic regulation of gene expression. Nat. Rev. Genet. 2015, 16, 71-84. [CrossRef] [PubMed]

112. Vastenhouw, N.L.; Brunschwig, K.; Okihara, K.L.; Muller, F.; Tijsterman, M.; Plasterk, R.H. Gene expression: Long-term gene silencing by RNAi. Nature 2006, 442, 882. [CrossRef] [PubMed]

113. Mao, H.; Zhu, C.; Zong, D.; Weng, C.; Yang, X.; Huang, H.; Liu, D.; Feng, X.; Guang, S. The Nrde pathway mediates small-RNA-directed histone $\mathrm{H} 3$ lysine 27 trimethylation in Caenorhabditis elegans. Curr. Biol. 2015, 25, 2398-2403. [CrossRef]

114. Lev, I.; Seroussi, U.; Gingold, H.; Bril, R.; Anava, S.; Rechavi, O. MET-2-Dependent H3K9 methylation suppresses transgenerational small RNA inheritance. Curr. Biol. 2017, 27, 1138-1147. [CrossRef] [PubMed] 
115. Liu, N.; Landreh, M.; Cao, K.; Abe, M.; Hendriks, G.J.; Kennerdell, J.R.; Zhu, Y.; Wang, L.S.; Bonini, N.M. The microRNA miR-34 modulates ageing and neurodegeneration in Drosophila. Nature 2012, 482, 519-523. [CrossRef] [PubMed]

116. Kennerdell, J.R.; Liu, N.; Bonini, N.M. MiR-34 inhibits polycomb repressive complex 2 to modulate chaperone expression and promote healthy brain aging. Nat. Commun. 2018, 9. [CrossRef] [PubMed]

117. Yu, Y.; Nangia-Makker, P.; Farhana, L.; Majumdar, A.P.N. A novel mechanism of lncRNA and miRNA interaction: CCAT2 regulates miR-145 expression by suppressing its maturation process in colon cancer cells. Mol. Cancer 2017, 16. [CrossRef] [PubMed]

118. Huang, P.H.; Plass, C.; Chen, C.S. Effects of histone deacetylase inhibitors on modulating H3K4 methylation marks-A novel cross-talk mechanism between histone-modifying enzymes. Mol. Cell. Pharmacol. 2011, 3, $39-43$.

119. Du, J.; Johnson, L.M.; Jacobsen, S.E.; Patel, D.J. DNA methylation pathways and their crosstalk with histone methylation. Nat. Rev. Mol. Cell Biol. 2015, 16, 519-532. [CrossRef]

120. Liu, F. Enhancer-derived RNA: A Primer. Genom. Proteom. Bioinform. 2017, 15, 196-200. [CrossRef]

121. Bose, D.A.; Donahue, G.; Reinberg, D.; Shiekhattar, R.; Bonasio, R.; Berger, S.L. RNA binding to CBP stimulates histone acetylation and transcription. Cell 2017, 168, 135-149. [CrossRef] [PubMed]

(C) 2019 by the authors. Licensee MDPI, Basel, Switzerland. This article is an open access article distributed under the terms and conditions of the Creative Commons Attribution (CC BY) license (http://creativecommons.org/licenses/by/4.0/). 